\title{
“ELE MILITOU NO SONHO DE VER OS MÚSICOS ENGAJADOS POLITICAMENTE"
}

\section{"HE FOUGHT DREAMING TO SEE MUSICIANS POLITICALLY ENGAGED"}

\author{
Entrevista com Flávia Toni
}

RT: Como filha de Toni, como the parece seu legado?

Flávia Toni: Prezado Marcos, responder a essa questão sob o plano da intimidade - que só se tornou maior com a proximidade da morte dele - situa a análise da obra na perspectiva da criação porque acompanhei, como meus irmãos, o nascimento das ideias e da bricolagem.

Todos os domingos, escolhíamos filmes para meus pais assistirem e, certa vez, thes mostramos a história de Dido Elizabeth Belle, no filme Belle, de Amma Asante (2013). Conversamos longamente sobre o filme e a questão do tráfico negreiro - principalmente a respeito da participação dos comerciantes ingleses - e, alguns dias depois, me lembrei de um outro filme, sobre o pintor J. M. W. Turner, Sr. Turner, de Mike Leigh (2014). Falamos sobre as lindas marinas que ele gostava de pintar, e eu localizei, na internet, a tela $\bigcirc$ navio negreiro. Na sequência, uma coisa leva à outra, procuramos para ele os poemas de Heinrich Heine e Castro Alves sobre o assunto. Durante aquelas semanas, ele só falava sobre isso; veio à sua memória uma figura cujo apelo era sobretudo a melodia que evocava, o Fanfan la Tulipe, por causa de um filme de Gérard Philippe. Ou seja, a melodia era mais importante do que o personagem do filme, porque ele escutara dizer, em algum lugar, que era uma melodia muito antiga, da época da Revolução Francesa. E foi Eduardo, meu filho, que localizou a melodia para ele, e juntos transcreveram-na. $\bigcirc$ último componente da estrutura, o coral de Bach que ele cita, só após sua morte me dei conta, é de uma cantata que gravou no primeiro LP da Orquestra de Câmara de São Paulo. $O$ ciclo se fechava: escreveu a peça, mas ainda não estava satisfeito - quis fazer um prólogo; uma vez completada, entregou-a a Cláudio Cruz, que fez a estreia, com o 
prólogo, em 19 de março - dia de São José, aniversário dos netos mais velhos - seis dias antes de ele morrer.

Há um texto feito para o programa do dia 19 de março, onde essa gênese vem explicada aproximadamente da maneira que aqui está, porque no texto uso partes da fala dele.

RT: $\bigcirc$ que mais a Sra. teria a dizer sobre o prof. Toni como compositor? A Sra. chegou a acompanhar outros processos criativos dele? Se sim, poderia nos relatar? Como a Sra. situaria o conjunto de sua obra no contexto da constelação de compositores que viveram intensamente o século XX? Como foi o caso de seu pai?

Flávia Toni: Meu pai passou a compor mais no final da vida, se levarmos em conta que ele tem um catálogo relativamente pequeno e viveu 91 anos. Mas a criação era para ele algo extremamente passional; ele compunha quando gostava de um poema - no caso das canções ou de um músico, a quem dedicava a obra, e aqui me refiro aos recitativos.

Mas o grande processo criativo que pudemos acompanhar - e novamente no plural: eu, meus irmãos, meus filhos - foi o CD que ele fez para o Sesc. Estão ali as obras que ele escolheu, sem restrições, as coisas que quis contar e até as aquarelas que gostava de pintar.

RT: Sabemos que o prof. Toni foi um admirador crítico de Mário de Andrade, uma de suas especialidades. De que maneira as trajetórias dos dois se cruzam?

Flávia Toni: Eu e meu pai nunca conversamos sobre o Mário de Andrade. Ele apenas me falou, mais de uma vez, que o encontrou certa vez saindo da Discoteca Pública. $\bigcirc$ autor do Ensaio [sobre a música brasileira (1928)] observou que ele pegara emprestada uma partitura da Sinfonia n." 5, de Beethoven. Mário teria dito: "Ótima escolha! Analise esta obra com o cuidado que ela merece!"

Mas sem dúvida os dois se assemelham enormemente: 1) Porque apostaram naquilo que as instituições poderiam trazer de positivo e duradouro para a música; Mário, através de todas as coisas que construiu à frente do Departamento de Cultura (quarteto, trio, corais, 
programação com orquestra sinfônica, para falar muito pouco, porque já escrevi bastante a este respeito); meu pai, com a criação da Orquestra Jovem, Orquestra de Câmara de São Paulo, Escola Municipal de Música, Departamento de Música da ECA-USP, entre outros. 2) Porque militaram no sonho de ver os artistas músicos engajados politicamente. 3) Porque foram eles os que criaram o maior número de empregos simultâneos para os músicos da cidade de São Paulo, tanto professores quanto instrumentistas. 4) E porque ambos apostaram que era necessário renovar o repertório, estimulando a criação do compositor próximo.

RT: E o que a Sra. sabe sobre os encontros dele com Heitor Villa-Lobos?

Flávia Toni: Meu pai conheceu Villa-Lobos na condição de fagotista do Teatro Municipal no início da década de 1950. Ele não se aproximou do compositor para mostrar as obras que escrevia; ele inclusive solicitou ao maestro que autografasse um caderno de assinaturas, além de uma partitura do Uirapuru.

RT: Como o prof. Toni via a relação entre a música chamada popular e a tradição clássica europeia?

Flávia Toni: Do modo como coloca tua pergunta, digo que ele aproximava, na verdade, a música popular à música folclórica. No caso do Brasil, quando se referia à música popular, ele falava da música comercial, embora salvaguardasse os autores que hoje são clássicos, como Chico Buarque.

Mas o pouco que conversei com ele sobre esse assunto foi para falarmos sobre Béla Bartók.

RT: E o que vocês conversavam sobre ele?

Flávia Toni: Meu pai adorava a obra dele e se lembrava de muitas situações onde tocou ou regeu certas peças do compositor húngaro.

Na verdade, houve mais situações de tocar do que reger porque, como fagotista, ele tocou com vários maestros. Das experiências marcantes, ele me contou sobre a estreia no Brasil do Mandarim, com o Balé do Quarto Centenário, em 1954. 
Mas ele era tão "tiete" que ficou mesmo emocionado quando visitou uma sala usada por Bartók no Conservatório de Budapeste.

RT: Sabemos que o filho de Béla Bartók, Peter, publicou um livro chamado My father. A Sra. tem algum plano de fazer algo assim?

Flávia Toni: Não tenho. Apesar de ele ter sido um homem importante em várias esferas da vida cultural do país, acho que a proximidade familiar prejudicaria a narrativa.

\section{Sobre a entrevistada}

Eleita em 2017 para a cadeira n 40 da Academia Brasileira de Música, cujo patrono é Mário de Andrade, antes ocupada por Renato Almeida e por Vasco Mariz, Flávia Camargo Toni é mestre e doutora em Artes, livre-docente, pesquisadora e professora titular do Instituto de Estudos Brasileiros (IEB/USP). Como musicóloga, especializou-se em questões envolvendo a literatura musical de Mário de Andrade, Modernismo e Música, e vida e obra de Camargo Guarnieri. Atuou em conjuntos musicais como instrumentista de viola da gamba e de violoncelo, e em 1973 participou da I Bienal Internacional de Música realizada em São Paulo. Fez cursos de especialização nos Estados Unidos e na França e atuou em congressos no Brasil e no exterior. É responsável pela edição crítica de obras de Mário de Andrade, bem como de sua correspondência com Luciano Gallet e com Camargo Guarnieri. Organizou o levantamento das fontes sobre as estadias de Villa-Lobos em São Paulo em estudo que trata da relação desse compositor com o autor de Macunaíma entre 1922 e 1945. Autora de vários livros e capítulos em obras coletivas sobre música, publicou dezenas de artigos em periódicos brasileiros e estrangeiros. Destaque especial merece sua atuação como orientadora e supervisora de dissertações de mestrado e teses de doutorado.

Recebido em 03/02/2018

Aprovado em 03/02/2018 